\title{
Kebersihan Organ Kewanitaan dan Kejadian Keputihan Patologi pada Santriwati di Pondok Pesantren Al Munawwir Yogyakarta
}

\author{
Tri Indah Setiani ${ }^{1}$, Tri Prabowo², Dyah Pradnya Paramita ${ }^{3}$ \\ ${ }^{1,3}$ Sekolah Tinggi IImu Kesehatan Alma Ata Yogyakarta \\ Jalan Ringroad Barat Daya No 1 Tamantirto, Kasihan, Bantul, Yogyakarta \\ ${ }^{2}$ Program Studi Keperawatan Politeknik Kesehatan Kementrian Kesehatan Yogyakarta \\ Jalan Tata Bumi No. 3, Sleman, Daerah Istimewa Yogyakarta
}

\begin{abstract}
Abstrak
Asia pada tahun 2013 menunjukkan prosentase masalah kesehatan reproduksi tentang kejadian keputihan patologis sebanyak (76\%). Kejadian keputihan yang ada di daerah Yogyakarta sebanyak (68\%), kejadian keputihan yang ada di kabupaten Bantul sebanyak (45\%) lebih tinggi dibandingkan pondok pesantren Al Munawwir (59,6\%). Tujuan penelitian ini untuk mengetahui hubungan perilaku menjaga kebersihan organ kewanitaan dengan kejadian keputihan pada santriwati di pondok Al Munawwir Yogyakarta 2014. Jenis penelitian ini menggunakan survey analitik dengan metode Cross Sectional. Populasi santriwati yang mengalami keputihan berjumlah 164 santriwati, dengan menggunakan rumus purposive sampling di dapat jumlah sampel 89 responden, Analisis data yang digunakan adalah Chi-Square. Hasil penelitian perilaku menjaga kebersihan organ kewanitaan pada santriwati di pondok Al Munawwir Yogyakarta masuk dalam kategori berperilaku kurang yaitu sebesar (62,9\%), angka kejadian keputihan patologi pada santriwati di pondok Al Munawwir Yogyakarta sebesar (59,6\%) dan hasil $\chi^{2}$ adalah 8,881 (>8,760). Kesimpulan ada hubungan antara perilaku menjaga kebersihan organ kewanitaan dengan kejadian keputihan di pondok pesantren Al Munawwir Yogyakarta 2014.
\end{abstract}

Kata Kunci: perilaku menjaga kebersihan, keputihan

\section{Healthy Reproductive Organ and The Incidence of Pathology Vaginal Discgarge on Santriwati in Pondok Pesantren Al Munawwir Yogyakarta}

\begin{abstract}
Asia in 2013 showed prosentase reproductive health problems of the pathological vaginal discharge were $76 \%$. The incidence of vaginal discharge in the regions Yogyakarta about $68 \%$, in district Bantul about $45 \%$ higher than Pondok Pesantren Al Munawwir (59.6\%). The purpose of this study was to know relationship between healthy reproductive organ and the incidence of pathology vaginal discgarge on santriwati in Pondok Pesantren Al Munawwir Yogyakarta. The study used survey analytic with cross sectional design. The population of santriwati that experienced vaginal discharge were 164 santriwati. Samples was obtaine by purposive sampling which consisted of 89 respondents, analysis the data was used chi-square. The results of study showed that healthy reproductive organ on santriwati at Pondok Pesantren Al Munawwir Yogyakarta included was $62.9 \%$ in less category, incidence of pathology vaginal discharge on santriwati at the cabin al munawwir yogyakarta were $59.6 \%$ and the result of $\chi^{2}$ were 8.881 (>8.760). In conclusion, there was a correlation between healthy reproductive organ and the incidence of pathology vaginal discgarge on santriwati in Pondok Pesantren Al Munawwir Yogyakarta.
\end{abstract}

Keywords: healthy reproductive organ, vaginal discharge

Info Artikel:

Artikel dikirim pada 10 Januari 2015

Artikel diterima pada 10 Januari 2015 


\section{PENDAHULUAN}

World Health Organization (WHO) mendefinisikan kesehatan adalah suatu kondisi sejahtera jasmani, rohani, dan sosial ekonomi, bukan hanya bebas dari penyakit atau kecacatan. Kesehatan reproduksi adalah suatu keadaan sejahtera fisik, mental, dan sosial secara utuh, yang tidak sematamata bebas dari penyakit atau kecacatan dalam semua hal yang berkaitan dengan sistem reproduksi dan fungsi-fungsinya serta prosesnya(1).

Menurut WHO masalah kesehatan mengenai reproduksi wanita yang buruk telah mencapai 33\% dari jumlah total beban penyakit yang menyerang pada wanita diseluruh dunia dan jumlah wanita di dunia yang pernah mengalami keputihan $75 \%$, sedangkan wanita Eropa yang mengalami keputihan sebesar $25 \%(2)$. Angka ini lebih besar dibandingkan dengan masalah reproduksi pada kaum laki-laki yang hanya mencapai $12,3 \%$ pada usia yang sama dengan kaum wanita. Data tersebut menunjukkan bahwa keputihan pada wanita di dunia, Eropa, dan di Indonesia cukup tinggi. Kesehatan reproduksi dikalangan wanita harus memperoleh perhatian yang serius, salah satunya adalah keputihan yaitu masalah yang berhubungan dengan organ seksual wanita. Keputihan biasanya disebabkan oleh jamur atau virus bakteri yang tentu saja masalah ini amat mengganggu penderita. Karena biasanya wanita akan mengeluarkan aroma yang tidak sedap dari organ intimnya(3).

Untuk angka kejadian masalah kesehatan reproduksi yang ada di Asia sebanyak $76 \%$ yang mengalami keputihan. Berdasarkan data statistik tahun 2009 jumlah remaja putri di DIY yaitu 2,9 juta jiwa berusia 15-24 tahun 68\% mengalami keputihan patologi. Berdasarkan data dari Dinas Kesehatan Kabupaten Bantul 2013, jumlah remaja yang dilayani dalam program kesehatan reproduksi terdapat 89815 jiwa, remaja yang terinfeksi Penyakit Menular Seksual (PMS) sebanyak $45 \%(4)$.

Banyaknya wanita yang mengalami keputihan ini disebabkan karena beberapa hal salah satunya adalah kurangnya menjaga kebersihan organ reproduksi. Pembersihan alat kelamin ini memang mutlak dibutuhkan. Keputihan dapat dicegah dengan dua cara, yaitu dengan budaya hidup yang sehat dan dengan cara hidup yang sehat. Cara hidup yang sehat adalah bagaimana cara dapat menjaga kebersihan dari alat kelamin diri sendiri, misalnya dengan rajin membersihkannya ataupun rajin untuk mengganti celana dalam yang dipakai. Hal yang perlu diperhatikan dalam memilih celana dalam adalah bahan yang digunakan sebaiknya terbuat dari bahan katun sehingga dapat menyerap keringat dan membiarkan kulit bernapas. Selain itu, hindari menggunakan pakaian dalam yang terlalu ketat karena selain gerah, juga menyebabkan peredaran darah tidak lancar(5).

Kebersihan daerah kewanitaan juga bisa dijaga dengan sering mengganti pakaian dalam, paling tidak sehari dua kali setelah mandi. terutama bagi wanita aktif dan mudah berkeringat harus pelu di perhatikan, agar tidak terjadi kelembaban pada organ kewanitaan maka harus sering mengganti celana dalam minimal 2 kali sehari(5).

Dari hasil studi pendahuluan pada tanggal 22 Maret 2014 di temukan sekitar 98 santriwati yang mengalami keputihan dari 164 santriwati di pondok Al Munawwir Yogyakarta. Tujuan penelitian adalah untuk mengetahui hubungan perilaku kebersihan organ kewanitaan dengan kejadian keputihan patologi pada santriwati di pondok Al Munawwir Yogyakarta tahun 2014.

\section{BAHAN DAN METODE}

Penelitian ini menggunakan metode survey analitik yang bertujuan untuk menjelaskan hubungan antara dua variabel yang diteliti, dari obyek yang mempunyai unit atau individu yang cukup banyak ${ }^{6}$. Rancangan penelitian dalam penelitian ini adalah menggunakan cross sectional. Populasi dalam penelitian ini adalah 164 santri putri di pondok pesantren Al Munawwir Yogyakarta. Sampel yang diambil 98 santriwati yang mengalami keputihan di pondok pesanteren Al Munawir, dan sampel yang memenuhi kriteria inklusi dan eksklusi. Cara pengambilan sampel ini menggunakan teknik purposive Sampling. Lokasi penelitian dilakukan di Pondok Al Munawwir Krapyak Yogyakarta. Penelitian dilakukan pada 26-29Juni 2014. Alat pengumpulan data yang digunakan adalah kuesioner. Variabel terkait yaitu perilaku kebersihan organ kewanitaan. Variabel bebas yaitu kejadian keputihan.

\section{HASIL DAN BAHASAN}

\section{Karakteristik Responden}

Hasil penelitian sesuai Tabel 1 yaitu pengambilan responden berdasarkan pendidikan dan umur responden. Yang pertama dilihat dari pendidikan responden, pendidikan merupakan salah satu ukuran dalam status kesehatan(7). Pendidikan merupakan hal utama dalam peningkatan sumber daya manusia. Pendidkan juga merupakan gejala universal pada manusia yang di dalamnya terdapat nilai-nilai untuk diintegrasikan dalam realitas kehidupan sosial kemasyarakatan, karena pendidikan sebagai proses 
Tabel 1. Distribusi Frekuensi Umur 17-24 Tahun dan Pendidikan Santriwati di Pondok Al Munawwir Krapyak Yogyakarta 2014

\begin{tabular}{lcc}
\hline \multicolumn{1}{c}{ Keterangan } & $\mathbf{n}$ & $\mathbf{\%}$ \\
\hline Umur & & \\
17 Tahun & 0 & 0 \\
18-20 Tahun & 13 & 14 \\
21-22 Tahun & 34 & 34 \\
23-24 Tahun & 42 & 52 \\
Pendidikan & & \\
SMP & 26 & 29,2 \\
SMA & 33 & 31,7 \\
S1 & 30 & 33,1 \\
Jumlah & 98 & 100,0 \\
\hline
\end{tabular}

Sumber: Data Primer Tahun 2014

pemanusiaan manusia, maka keberlangsungan pendidikan harus didukung oleh semua komponen yang ada agar pendidikan menjadi suatu alat komunikasi(8). Mereka yang memiliki pendidikan yang lebih tinggi lebih berorientasi pada tindakan preventif, tahu lebih banyak tentang masalah kesehatan dan memiliki setatus kesehatan lebih baik. Pada perempuan semakin tinggi pengetahuan atau pendidikan, semakin rendah angka kejadian keputihan patologi. Pondok Al Munawwir terdapat pendidikan SMP, SMA dan S1 sesuai dengan karakteristik yang akan diambil. Pendidikan ini untuk mengantisipasi agar responden tersebut paham akan sebuah penelitian dan untuk mengethui seberapa jauh pengetahuan tentang masalah-masalah kesehatan reproduksi. Responden yang mengalami keputihan yaitu, SMP 26 orang $(29,2 \%)$, SMA sebanyak 33 orang $(31,7 \%)$ dan pendidikan $\mathrm{S} 1$ terdapat 30 responden (33,1\%).

Karakteristik umur yang diambil untuk penelitian yaitu umur 17-24 tahun karena perubahan masa remaja menuju masa dewasa, karena masa ini banyak mengalami permasalahan-permasalahan yang dialami oleh remaja, seperti kejadian keputihan(7). Dari hasil penelitian yang dilakukan di pondok Al Munawwir Yogyakarta angka kejadian keputihan yang banyak dialami remaja berusia 23-24 tahun dari 98 responden sebanyak (52\%) responden.

\section{Perilaku Menjaga Kebersihan}

Berdasarkan Tabel 2 menunjukkan bahwa dari 98 responden sebagian besar memiliki perilaku yang baik menjaga kebersihan organ kewanitaan sebesar 33 orang $(37,1 \%)$, resonden yang memiliki perilaku cukup sebanyak 30 orang (33,7\%), dan responden yang memiliki perilaku kurang sebanyak 26 orang $(29,2 \%)$.

Perilaku responden masih berperilaku kurang yaitu 26 orang $(29,2 \%)$, dan responden yang
Tabel 2. Distribusi Frekuensi Perilaku Menjaga Kebersihan Organ Kewanitaan pada Santriwati di Pondok Al Munawwir Krapyak Yogyakarta 2014

\begin{tabular}{llcc}
\hline Variabel & Hasil Ukur & $\mathbf{n}$ & $\%$ \\
\hline Perilaku Menjaga & Baik & 33 & 37,1 \\
Kebersihan Organ & Cukup & 30 & 33,7 \\
Kewanitaan & Kurang & 26 & 29,2 \\
Jumlah & & 98 & 100,0 \\
\hline
\end{tabular}

Sumber: Hasil Analisis Data

berperilaku cukup sebanyak 30 orang (33,7\%). Dari jumlah perilaku responden tersebut, kebanyakan melakukan personal haygienenya masih banyak yang tidak sesuai dengan teori. Di lihat dari pengisian kuesioner banyak sekali responden mengisi kuesioner dengan jawaban tidak sesuai dengan teori seperti: pertama mengenai kebersihan tangan, responden banyak yang masih mengabaikan masalah cuci tangan terutama cuci tangan sebelum mandi, BAK/BAB, dan sebelum ganti pembalut. Kalau sesudah melakukan tindakan yang menyentuh organ kewanitaan selalu cuci tangan. Menurut Shadini cuci tangan yang benar adalah cuci tangan menggunakan sabun terlebih dahulu kemudian baru mencuci organ kewanitaan sebelum dan sesudah melakukan tindakan seperti mandi, BAK/BAB, dan saat ganti pembalut bila menstruasi(5).

Sebagian besar responden menggunakan pakaian dalam tidak sesuai dengan teori, yaitu responden masih banyak menggunakan celana dalam yang tidak dari bahan katun dan juga menggunakan celana dalam yang sedikit ketat, untuk masalah penggunaan air banyak responden yang tidak menggunakan air yang bersih mengalir, dan air hangat, responden masih banyak menggunakan sabun mandi atau sabun pembersih vagina yang di jual di toko-toko seperti sabun sirih. Menurut Shadini penggunaan produk-produk pembersih vagina tidak dianjurkan karena membunuh kumankuman yang di butuhkan di sekitar vagina(5). Sebagian besar responden masih ada yang belum tahu tentang cara membersihkan organ kewanitaan yang benar.

\section{Kejadian keputihan}

Berdasarkan Tabel 3 bahwa angka kejadian keputihan fisiologi 36 orang $(40,4 \%)$, dan angka kejadian keputihan patologi 53 orang $(59,6 \%)$. Masalah keputihan yang dialami oleh responden yaitu keputihan terus menerus tidak ada jeda, lamanya kurang lebih 2-3 tahun, dan sebagian mengalami keputihan yang terasa panas, gatal, berbau dan nyeri di organ kewanitaan. Sahdine mengatakan bahwa 
keputihan yang dialami responden di atas masuk dalam kategori keputihan patologi(5).

Tabel 3. Distribusi Frekuensi Kejadian Keputihan pada Santriwati di Pondok Al Munawwir Krapyak Yogyakarta 2014

\begin{tabular}{llcc}
\hline Variabel & Hasil Ukur & $\mathbf{n}$ & $\%$ \\
\hline \multirow{3}{*}{ Kejadian Keputihan } & Fisiologi & 36 & 40,4 \\
Jumlah & Patologi & 53 & 59,6 \\
& & 98 & 100,0 \\
\hline
\end{tabular}

Sumber: Hasil analisis data

Keputihan adalah cairan yang keluar dari kemaluan selain darah dan bukan sebuah penyakit, akan tetapi merupakan gejala dari penyakit. Keputihan di bagi menjadi dua keputihan yaitu fisiologi dan patologi. Keputihan fisiologi adalah cairan keputihan yang keluar dari vagina, tidak berbau busuk, tidak terasa nyeri, gatal dan panas. Adapun keputihan patologi adalah cairan keputihan yang berubah warna, terasa gatal, nyeri dan terasa panas.

\section{Hubungan Perilaku Menjaga Kebersihan dan Kejadian Keputihan}

Distribusi frekuensi hubungan perilaku menjaga kebersihan dan kejadian keputihan pada santriwati di Pondok Al Munawwir Krapyak Yogyakarta tahun 2014 dapat dilihat pada Tabel 4.

\section{Tabel 4. Distribusi Frekuensi Hubungan Perilaku Menjaga Kebersihan dan Kejadian Keputihan pada Santriwati di Pondok Al Munawwir Krapyak Yogyakarta 2014.}

\begin{tabular}{|c|c|c|c|c|c|c|}
\hline \multirow{3}{*}{$\begin{array}{c}\text { Perilaku } \\
\text { Menjaga } \\
\text { Kebersihan } \\
\text { Organ } \\
\text { Kewanitaan }\end{array}$} & \multicolumn{4}{|c|}{ Kejadian Keputihan } & \multirow{3}{*}{$\chi^{2}$} & \multirow{3}{*}{$p$-value } \\
\hline & \multicolumn{2}{|c|}{ Fisiologi } & \multicolumn{2}{|c|}{ Patologi } & & \\
\hline & $\mathbf{n}$ & $\%$ & $\mathbf{n}$ & $\%$ & & \\
\hline Baik & 19 & 21,3 & 14 & 15,7 & & \\
\hline Cukup & 12 & 13,5 & 18 & 20,2 & 8,881 & 8,760 \\
\hline Kurang & 5 & 5,6 & 21 & 23,6 & & \\
\hline Total & 36 & 40,4 & 53 & 59,6 & & \\
\hline
\end{tabular}

Sumber: Hasil Analisis Data

Hasil uji chi-square di atas, diperoleh nilai $\chi^{2}$ sebesar 8,881 ,sedangkan $p$-value 8,760 . Dengan demikian $\chi_{\text {hitung }}^{2}>p$-value $(8,881>8,760)$, maka $\mathrm{H}_{0}$ ditolak dan $\mathrm{Ha}$ diterima sehingga ada hubungan antara kebersihan organ kewanitaan dengan kejadian keputihan. Hasil yang segnifikan ini disebabkan karena banyaknya responden yang mengalami keputihan patologi sebesar 53 orang $(59,6 \%)$. Bila perilaku respoden baik maka angka kejadian keputihan patologi menurun sebanyak 14 orang $(15,7 \%)$, bila perilaku responden cukup maka angka kejadian keputihan patologi meningkat sebanyak 18 orang $(20,2 \%)$, dan bila perilaku responden tersebut kurang maka angka kejadian keputihan meningkat sebanyak 21 orang $(23,6 \%)$. Sesuai teori yang ada bila perilakunya baik maka angka kejadian keputihan bisa di sebabkan karena faktor-faktor yang lain menurut Shadini kejadian keputihan di sebabkan berbagai macam seperti, pengaruh hormon, personal hygiene, kecapkan, adanya penyakit di mulut rahim dan kelainan anatomis pada organ kewanitaan(5).

\section{SIMPULAN DAN SARAN}

Berdasarkan hasil penelitian dan pembahasan mengenai hubungan perilaku menjaga kebersihan organkewanitaan dengan kejadian keputihan pada santriwati di pondok Al Munawwir Krapyak Yogyakarta pada tahun 2014 yang telah dilaksanakan dapat disimpulkan sebagai berikut responden sebagian besar memiliki tingkat perilaku yang baik tentang kebersihan organ kewanitaan sebesar 33 orang $(37,1 \%)$, responden sebagian besar mengalami keputihan patologis sebesar 53 orang $(59,6 \%)$, ada hubungan perilaku menjaga kebersihan organ kewanitaan dengan kejadian keputihan pada santriwati di pondok Al Munawwir Krapyak Yogyakarta pada tahun 2014 dengan jumlah $\chi^{2}$ sebesar 8,881. Saran bagi santriwati agar lebih baik dalam perilaku menjaga kebersihan organ kewanitaan.

\section{RUJUKAN}

1. Widyastui Y, dkk. Kesehatan Reproduksi. Yogyakarta: Fitramaya; 2009.

2. Zubier F. Keputihan kapan perlu dicemaskan [internet]. 2002 [cited 2014]. Available from: http://portal.cbn.net.id/cbprt//Cybermed/detail. aspx? $x=$ Health +Woman\&y=Cybermed $\% 7 \mathrm{C0} \%$ 7C0\%7C14\%7C307.

3. Prawiroharjo S. IImu Kandungan. Jakarta: Yayasan Bina Pustaka Sarwono Prawiroharjo; 2007.

4. Dinas Kesehatan Yogyakarta. Profil Kesehatan DIY. Yogyakarta; 2013.

5. Shadini. Penyakit Wanita. Yogyakarta: Citra Maya; 2012.

6. Notoatmojo S. Metodelogi Penelitian Kesehatan. Jakarta: Rineka Cipta; 2006.

7. Intan KS. Kesehatan Reproduksi Untuk Mahasiswa Kebidanan dan Keperawatan. Jakarta: Salemba Medika; 2006.

8. Yunus M. Perilaku Pacaran Pada Remaja. Universitas Gajah Mada Yogyakarta; 2007. 